\title{
UPDATED PUBLICATIONS NOTICE
}

\section{1) Index of Titles and Authors in Environmental Conservation*}

The Index for 1974-86 (both inclusive), and its first Supplement (covering the years 1987 and 1988), are still available from the undersigned at the price (for the two, including surface postage) of US $\$ 40 \dagger$ or $60 \dagger$ Swiss francs as long as stocks last. It is anticipated that most of our subscribers, at least, will wish to possess a copy of this pioneering Index of which the first part, with its 9,399 entries occupying 159 pages in the format of the Journal, alone approaches twice the basic length of one of our issues but still costs less! Moreover this price will include full payment also for a further Supplement, covering the 7 years 1989-95, which is now in advanced preparation and due to be sent free to all registered purchasers of the original Index.

Referencing, as it does, seemingly the vast majority of leading Authors and topics that emerged during the formative and subsequent years of the environmental-conservational movement or 'revolution', the Index with its Supplements should represent a valuable tool for researchers and a propitious guide for writers. This was borne out by our own experience during its original compilation, when already it proved to be a most useful work of reference, '.... altogether constituting a unique chronicle of the environmental-conservational concerns of modern times' (according to the Foreword by the then Executive Director of the United Nations Environment Programme, Dr Mostafa K. Tolba).

\section{2) Full Sets and Back Numbers of Environmental Conservation}

We still have a few complete sets of Environmental Conservation, from its beginning with the Spring issue of 1974 , available for purchase by or for worthy 'homes'. Back numbers can usually be supplied to fill gaps at a cost of US $\$ 10$ apiece.

\section{3) Copies of Ecosystem Theory and Application}

We also have some residual copies available (at US $\$ 40$ each, including postage) of Ecosystem Theory and Application, published in 1986 by John Wiley \& Sons in the President's series of Environmental Monographs \& Symposia.

\section{4) Publication of first book of Environmental Challenges}

In July 1993 the Foundation for Environmental Conservation co-published the first of its planned 'Original Paperbacks: Readers by Leaders'. Entitled Environmental Challenges: From Stockholm to Rio and Beyond, it has a Foreword by Mrs Gro Harlem Brundtland and an Introduction by its Editors, Mohammad Nazim \& Nicholas Polunin, with early chapters by Mostafa K. Tolba, Nafis Sadik, Birgitta Dahl, and Arthur H. Westing; included among later chapters are those headed by Bert Bolin, Sandro M. Radicella, and Maurice F. Strong. The price (including postage) is US $\$ 12$ for individuals and US $\$ 20$ for institutions.

\section{5) Population and Global Security (Environmental Challenges II)}

This second book of our series of original paperback 'readers by leaders' has now been published as a 'Limited Geneva Edition for United Nations Population Fund (UNFPA) et al.' and, while stocks last, will be available from the undersigned at US $\$ 15$ for individuals or 25 for institutions - in both cases postage free (i.e. paid). Details of the Limited Edition are given on page 296 of this issue. It is to be followed by an updated World Edition through Cambridge University Press.

\section{6) Proceedings of our Fourth International Conference on Environmental Future (ICEF)}

Surviving With The Biosphere was published in December 1993 by Edinburgh University Press, 22 George Square, Edinburgh EH8 9LF, Scotland, UK, at $£ 85$ hardbound. Edited by Nicholas Polunin \& Sir John Burnett, 'This volume [of about 600 pages with numerous illustrations] details the urgent global action required to preserve' Mankind and Nature's all-too-fragile only habitat, The Biosphere, based on the presented contributions and lively discussions of a galaxy of leading conservationists at the Foundation's Budapest Conference. Norman Myers' review, published on page 377 of Environmental Conservation's 1994 Winter issue, ends '... the book warrants a place on the desk, not the library shelf, of every political leader and policymaker. If the three earlier conferences and books in the series had enjoyed such exposure, there might well have been less need for this fourth concerning The Biosphere's prospects of survival.

\section{7) World Who's Who and Does What in Environment \& Conservation}

After years of preparation, work is now proceeding apace on the Foundation's long-planned (and now styled and committed) World Who's Who and Does What in Environment \& Conservation. This is intended to contain, besides helpful Appendixes, detailed biographies of all who respond satisfactorily of the seemingly most eminent and/or active living men and women involved anywhere in its all-important duality of subjects. Being a large undertaking for a tiny office and sole Compiler, the first edition of this pioneering work will nevertheless contain more than 1,000 authorized biographies. It is expected to be available early in 1996, with valuable Appendixes indicating biographees by subject or theme, and by country - thus specifying who is involved and so 'does what', and where.

(MRS) LYNN M. CURME

Environmental Conservation

7 Chemin Taverney

1218 Grand-Saconnex

Geneva, Switzerland:

Tel. $(++4122) 7982383$ and 4

Fax $(++4122) 7982344$.

\footnotetext{
* Published quarterly by the Foundation and distributed by Elsevier Science.
}

$\dagger$ New prices in deference to increased postal rates and inflation. 